\title{
The Association between Metabolic Syndrome and Multiple Myeloma
}

\author{
Sophie C. Ragbourne ${ }^{a}$ Negar Maghsoodi ${ }^{a}$ Matthew Streetly ${ }^{b}$ \\ Martin A. Crook ${ }^{\mathrm{C}}$ \\ ${ }^{a}$ Department of Chemical Pathology, Guys and St Thomas's Hospital, London, UK; ${ }^{\text {b}}$ Department of Haematology, \\ Guys and St Thomas's Hospital, London, UK; 'Department of Chemical Pathology, Guy's and St Thomas' and \\ Lewisham and Greenwich Trust, London, UK
}

\section{Keywords}

Cytokines · Lipids · Metabolic syndrome · Metformin . Myeloma $\cdot$ Obesity $\cdot$ Paraprotein $\cdot$ Statins

\begin{abstract}
Multiple myeloma (MM) is a haematological malignancy arising from monoclonal proliferation of plasma cells in the bone marrow, resulting in the presence of paraproteins or M-protein in serum. The involvement of paraproteins produced by malignant plasma cells in the development of hyperlipidaemia and low-HDL cholesterol has been described, as has an association with MM and obesity, hypertension, and type 2 diabetes mellitus, and insulin resistance, that is, features of the metabolic syndrome (MS). There is an association between MS components, inflammatory cytokines, and the development of MM, and some drugs used in the treatment of MS such as statins and metformin may improve outcomes in MM.

(c) 2020 S. Karger AG, Basel
\end{abstract}

\section{Introduction}

Metabolic syndrome (MS) is a cluster of clinical features usually comprising obesity (central adiposity), with hyperglycaemia and insulin resistance, hypertension, and dyslipidaemia including hypercholesterolaemia, hypertriglyceridaemia, and low HDL cholesterol and may lead to type 2 diabetes mellitus (T2DM) and cardiovascular disease [1]. There is, however, no universal agreement on the definition of MS, with various suggestions proposed, such as that by the American Heart Association, the International Diabetes Federation, and the World Health Organisation (WHO) [1]. What is agreed upon is the fact that MS is becoming more prevalent given the wellknown trend in the growth of human obesity and the factors underlying this are increasing worldwide $[1,2]$.

The aim of this novel review is to explore the association between multiple myeloma (MM) and components of the MS. Together with central obesity, insulin resistance/hyperglycaemia, dyslipidaemia, and hypertension constitute the MS, widely acknowledged to be associated with increased cardiovascular events and more recently cancer incidence [1].

\section{Obesity}

Obesity is an essential component of MS and it is a heterogeneous condition associated with a myriad of pathological processes and disease states. Commonly measured according to the body mass index (BMI), whereby the weight in kilograms is divided by the square karger@karger.com www.karger.com/aha

(C) 2020 S. Karger AG, Base

Karger!
Prof. Martin A. Crook

Department of Chemical Pathology, Guy's Hospital

Guy's and St Thomas' and Lewisham and Greenwich Trust

Great Maze Pond, London SE19RT (UK)

martin.crook@doctors.org.uk 
of the height in metres, the WHO classifies obesity (BMI) into 3 distinct stages, namely: stage 1 (BMI 30-34.9), stage 2 (BMI 35-39.9), and stage 3 (BMI $\geq 40$ ). Globally, in 2016 , over 1.25 billion adults were found to be overweight (BMI 25-29.9), and 650 million were obese [1]. A BMI $>25$ was associated with increased all-cause mortality in a pulled analysis of 19 prospective studies that included 1.46 million individuals [2].

New adult cancer diagnoses attributable to increased BMI worldwide in 2012 was estimated at 481,000 cases, with the obesity-attributable cancer burden in the UK calculated to be 8.2 and $4.4 \%$ among women and men, respectively $[3,4]$. A quarter of these cases $(n=118,000)$ were potentially avoidable had populations maintained their recorded mean BMI of 1982 [3]. Moreover, a separate large prospective cohort study of over 900,000 US adults that analysed the relationship between BMI in 1982 and risk of death from cancer over a 16-year mean followup period, whilst controlling for other risk factors (RF), demonstrated that individuals with stage 3 obesity had a relative risk (RR) of death from any cancer of 1.52 (males) and 1.62 (females) compared to their normal-weight counterparts [5]. It is therefore understandable that, as the obesity epidemic continues to expand, there is increasing concern over the growing evidence that links this serious disease with many cancers, including MM [2, 5-9].

The second most common haematological malignancy, $\mathrm{MM}$ is an incurable cancer characterized by clonal proliferation of malignant plasma cells of B lymphocyte derivation and concomitant superfluous generation of monoclonal paraprotein, $[10,11]$. Several studies have identified excess body weight as an RF for MM development and mortality [5-7, 9, 12-18]. A meta-analysis of 19 prospective studies by Wallin and Larsson [7] reported a statistically significant increased incidence of MM in individuals classified as overweight $(R R=1.12)$ or obese $(\mathrm{RR}=1.21)$ compared to those within the normal-weight category; RR estimates of MM mortality were 1.15 and 1.54 for overweight and obese individuals, respectively [7]. Furthermore, MM risk and mortality were calculated to increase by 12 and $21 \%$ for every 5 -unit increment in BMI, correspondingly [7]. Similarly, Calle et al. [5] reported a significantly increased risk of MM mortality for individuals with a BMI of 25-29.9 $(\mathrm{RR}=1.18$; 95\% CI 1.01-1.39 [males]; $\mathrm{RR}=1.12 ; 95 \%$ CI $0.93-1.34$ [females]), a BMI of $30-34.9$ (RR $=1.44 ; 95 \%$ CI $1.10-1.89$ [males]; RR $=1.47 ; 95 \%$ CI 1.13-1.91 [females]), and a BMI of 35-39.9 ( $\mathrm{RR}=1.71 ; 95 \%$ CI $0.93-3.14$ [males]; $\mathrm{RR}=1.44 ; 95 \%$ CI 0.91-2.28 [females]) compared to in-
Table 1. Summary of studies showing an association between obesity and the risk of developing MM

\begin{tabular}{|c|c|}
\hline Study & Type of study \\
\hline Larsson and Wolk [6] & $\begin{array}{l}14,280 \text { individual cases plus a cohort } \\
\text { analysis }\end{array}$ \\
\hline Wallin and Larsson [7] & 15 cohort studies (metanalysis) \\
\hline Renehan et al. [9] & 282,137 individuals (systematic review) \\
\hline Hofmann et al. [13] & $\begin{array}{l}\text { Increased BMI and physical inactivity } \\
\text { increase the risk of MM }\end{array}$ \\
\hline $\begin{array}{l}\text { Lauby-Secretan et al. } \\
{[14]}\end{array}$ & $\begin{array}{l}\text { Expert opinion, review and metanalysis } \\
\text { showed that obesity is a risk factor for } \\
\text { MM }\end{array}$ \\
\hline Lichtman [15] & Obesity is associated with MM (review) \\
\hline Murphy et al. [16] & $\begin{array}{l}1.3 \text { million individuals (prospective } \\
\text { study) }\end{array}$ \\
\hline Teras et al. [17] & $\begin{array}{l}\text { Review of } 20 \text { prospective studies BMI } \\
\text { increased mortality }\end{array}$ \\
\hline Carson et al. [19] & Obesity is associated with MM (review) \\
\hline
\end{tabular}

dividuals within the normal-weight category. Moreover, a pooled analysis of MM mortality by Teras et al. [17] that included more than 1.5 million participants from 20 prospective cohorts demonstrated an elevated MM mortality in individuals who had a higher early-adult BMI (hazard ratio $[\mathrm{HR}]=1.22 ; 95 \%$ CI $1.09-1.35$ per $\left.5 \mathrm{~kg} / \mathrm{m}^{2}\right)$ and a higher BMI at cohort entry $(\mathrm{HR}=1.09 ; 95 \% \mathrm{CI} 1.03-1.16$ per $5 \mathrm{~kg} / \mathrm{m}^{2}$ ).

Evaluation of the joint effect of young adult and baseline BMI revealed that the heaviest females, both in early adulthood (BMI 25+) and at cohort entry (BMI 30+), were at an increased risk of MM mortality compared to individuals with a "normal" BMI at both time points (HR $=1.95,95 \%$ CI 1.33-2.86), although no such significant association was found in men. Indeed, excess body weight throughout adulthood appears to be an important RF for MM development and mortality $[13,17]$. In fact, a prospective study by Nagel et al. [12] in 578,000 adults demonstrated, through Cox regression models, that BMI was the most consistent RF for all blood cancers, especially in women, although no association between BMI and MM was found in males or females. The abundance of evidence that associates a raised BMI with MM has led to the recent establishment of obesity as a recognized RF for MM by the International Agency for Research on Cancer [14]. It has been proposed that the population level my- 
eloma burden could be reduced when considering obesity as the only modifiable RF [19].

That said, whether obesity effects the progression of monoclonal gammopathy of undetermined significance (MGUS) to MM remains uncertain. A case control study by Thompson et al. [20] that compared 100 MGUS cases that progressed to MM with 100 age-, gender-, and year of diagnosis-matched MGUS cases that did not progress to MM found no significant association between obesity and progression to MM. However, the study lacked information on recognized RF for MGUS progression and it is difficult to ascertain whether there is truly a lack of a relationship between these factors or whether these results were due to study underpowering. See Table 1 for a summary of studies showing an association between obesity and the risk of developing MM.

\section{Diabetes Mellitus}

$\mathrm{DM}$, and more specifically $\mathrm{T} 2 \mathrm{DM}$, has been linked to an increased risk of many cancer types [21-26]. A recent retrospective case review of 82 patients at various stages of their MM disease pathway reported that $58.5 \%$ of patients had one or more features consistent with MS, including some with T2DM [25]. Nevertheless, the evidence of the relation between hyperglycaemia and MM is conflicting [12, 27-31]. Khan et al. [27] found no association between the rates of self-reported DM and MM in The European Prospective Investigation into Cancer and Nutrition. Conversely, Nagel et al. [12] reported a positive correlation between blood glucose level and the risk of MM and high-grade B-cell lymphoma in men. Additionally, there was a trend toward significantly increased odds of MM in patients with T2DM in a meta-analysis of 10 studies $(\mathrm{OR}=1.22$; 95\% CI 0.98-1.53; $p=0.08)$ [29].

That said, although the authors addressed age, sex, and geographical location, other important confounders such as obesity and anti-diabetic therapy were not accounted for [29]. A prospective study of US adults documented an increased risk of mortality from MM in women who had a postload plasma glucose concentration $\geq 200 \mathrm{mg} / \mathrm{dL}$ (HR $=3.06$; 95\% CI 1.05-8.93) [28]. Likewise, a Taiwanese study of 310 patients that analysed the impact of preexisting T2DM on the prognosis of MM found that diabetic patients have around a $50 \%$ greater all-cause mortality than their non-diabetic counterparts $(\mathrm{HR}=1.509 ; 95 \% \mathrm{CI} 1.023-2.225 ; p=0.037)$, with a significantly higher rate of advanced stage and renal impairment at diagnosis [30].
$\mathrm{Wu}$ et al. [31] conducted a retrospective review of 1,240 MM patients to evaluate the impact of DM and anti-diabetic medications on MM clinical outcomes. T2DM and steroid-induced DM were present in 12.6 and $31.7 \%$ of the cohort, respectively. A significantly reduced overall survival (OS) was found in diabetic patients (median: 65.4 months) compared to nondiabetic controls (median: 98.7 months). In multivariate analysis, steroid-induced DM was a significant predictor of poor OS. Interestingly, metformin use was associated with decreased mortality and insulin analogues with increased mortality from progressive MM [31].

However, it is possible that the increased myeloma deaths in those with DM may be due to poorer health and difficulty tolerating anti-myeloma therapy which may include steroids which are diabetogenic. In addition, those on metformin therapy may have had better diabetes control than those on insulin therapy, which may have been a confounder.

\section{Hyperlipidaemia}

Hyperlipidaemia is another component of the MS and has been reported in patients with MGUS and MM, particularly the immunoglobulin (Ig)-A subtype [32-35]. Dyslipidaemia can present as an isolated laboratory finding, with lipid abnormalities that include hypercholesterolaemia, hypertriglyceridaemia, or even chylomicron syndrome, or in combination with its clinical manifestations, such as cutaneous xanthomas, hyperviscosity syndrome, or atherosclerosis [34-37]. A review of 53 cases by Misselwitz et al. [34] that compared hyperlipidaemic MM patients to patients with MM and a normal lipid status concluded a higher incidence of IgA paraprotein (53 vs. $21 \%)$, skin xanthomas (70\%), and hyperviscosity syndrome (26 vs. $2-6 \%$ ) in the former patient group [33]. There are also several case reports of acquired myelomarelated phenotypical presentation of Frederickson's type III (raised remnant or intermediate-density lipoproteins; IDL) and type V (raised chylomicron and very low-density lipoproteins) hyperlipoproteinaemia available in the literature [38-40]. Dyslipidaemia associated with MM may be relatively refractory to conventional lipid-lowering medications but responsive to successful MM treatment $[34,35,41]$.

Paraproteins have been implicated in the development of MM-associated hyperlipidaemia in a myriad of studies $[33,35,42,43]$. The mechanism through which this occurs is thought to be the binding of paraproteins to serum 
lipoproteins, tissue receptors, and lipoprotein lipase, with a resultant reduction in the clearance of lipoproteins [35, 37, 41-49]. Corsini et al. [43] described a patient with MGUS who had evidence of autoantibodies against the low-density lipoprotein (LDL) receptor, and this was paralleled by Nozaki et al. [41], who demonstrated, through Western blot analysis, the binding of IgA to the LDLbinding site of the LDL receptor in a patient with MM and autoimmune hyperlipidaemia. Similarly, another study revealed $\operatorname{IgA}$ autoantibodies to lipoprotein lipase in a patient with autoimmune hyperchylomicronaemia [37]. A case report by Taylor et al. [44] of a patient with MM, generalized plane xanthoma, and hyperlipidaemia illustrated, through immunohistochemical studies of cutaneous lesions and bone marrow, the deposition of IgG with LDL-cholesterol and IgG with $\beta$-lipoprotein, correspondingly.

A further study by Kilgore et al. [42] demonstrated an in vitro affinity of the Fab fragment of the IgA paraprotein to apolipoproteins $\mathrm{B}$ and $\mathrm{E}$ in a patient diagnosed with MM. Cortese et al. [45] compared the metabolism of IDL and LDL-cholesterol in 2 males with Frederickson's type III hyperlipoproteinaemia associated with MM [44].

Compared to controls, the fractional catabolic rate of IDL, the conversion of IDL to LDL, and the affinity of LDL to its receptor were impaired in patients with MM, and this was concluded to be due to the formation of Iglipoprotein complexes [46-49]. Many of the studies reported here are case reports of hyperlipidaemia and MM and the current literature is sparse regarding larger epidemiological studies, which would be an important area for future research.

However, it has been suggested that myeloma cells are dependent upon exogenous cholesterol for survival and that LDL cholesterol is an important antiapoptotic [50] Furthermore, there are data that some myeloma cell lines have defects in cholesterol biosynthesis with abnormality of demethylation of lanosterol to C-29 sterol intermediates [51]. It should also be remembered that an artifactually low HDL cholesterol can be caused by paraprotein interference in vitro with certain HDL assays in Waldenstrom's macroglobulinaemia [52].

\section{Hypertension}

Another feature of the MS is hypertension, and this has also been shown to be associated with MM. Chari et al. [53] reported a higher incidence of hypertension in MM patients. This was also confirmed by Patel and Cornell
[54], who also reviewed increased cardiovascular complications in MM, in part related to insulin resistance, DM, and dyslipidaemia in addition to hypertension. However, it is of course also possible that certain therapies used in MM such as steroids and the selective proteasome inhibitor carfilzomib may also evoke hypertension in some patients $[55,56]$.

\section{The Innate Immune System}

The Crook and Pickup hypothesis may also be pertinent in the context of MGUS and MM progression. Herein, a hypersensitive acute phase response occurs as part of a widespread activation of the innate immune system [57]. Numerous stressors, including infection, inflammation, and malignancy, can induce the release of proinflammatory cytokines, mainly tumour necrosis factor (TNF)- $\alpha$ and interleukin (IL)- 6 . These subsequently stimulate hepatic production of acute phase reactants, such as C-reactive protein, serum amyloid A, and complement, with marked changes in their serum concentration; metabolic pathways are also influenced with consequent insulin resistance and T2DM [21, 57-59]. Adipose tissue is an endocrine organ that has an active influence on metabolic, inflammatory, and endocrine pathways via the secretion of the aforementioned adipokines, in addition to adiponectin, leptin, and resistin [60-62].

\section{Cytokines and Inflammatory Mediators}

Carson et al. [19] hypothesized that the proinflammatory cytokine profile produced by obesity may impact oncogenesis at several points in the pathway of B-cell differentiation, thereby increasing the risk of MM development. IL-6 is a pleotropic cytokine with effects on numerous target cells through activation of the antiapoptotic Janus kinase (JAK)/signal transducer and activator of transcription 3 (STAT3) pathway [63, 64]. IL-6 is a powerful myeloma cell growth factor - within the bone marrow, IL-6 produced by both stromal or MM cells has been found to promote myeloma cell proliferation and survival [61-65]. IL-6 and its surrogate markers are poor prognostic factors in MM [66].

There is also a widely established positive relationship between BMI, insulin resistance, and chronic hyperinsulinaemia, which sequentially results in a reduction in the plasma concentration of hepatic insulin-like growth factor binding protein-1 and thus increased free bioactive 
insulin-like growth factor 1 (IGF-1) [67, 68]. The literature highlights the pertinent role of IGF-1 in the pathogenesis of $\mathrm{MM}$ as it functions to stimulate mitogenesis and survival of myeloma cell lines, as well as promoting MM cell secretion of vascular endothelial growth factor, which facilitates angiogenesis [19, 64, 69-73].

Inversely associated with body fat, adiponectin has anti-inflammatory, anti-atherogenic, and anti-diabetic properties [56, 57, 74, 75]. Its reduced expression may be associated with progression from MGUS to MM [58, 76, 77]. Dalamaga et al. [62] found a significantly increased risk of MM with reduced adiponectin and resistin levels by bivariate analysis in a case-control study that compared the levels of serum adiponectin, resistin, and leptin between 73 patients with MM to 73 age- and gendermatched controls. In the same study, no significant difference was found between the concentration of serum leptin in MM patients compared to controls (after adjusting for variables) despite prior evidence suggesting that the level of leptin, which is positively correlated with fat mass, appears to be higher in MM patients and that leptin concentration may reduce following treatment for myeloma [62, 78-83].

Similarly, a prospective study by Hofmann et al. [80] that evaluated the relationship between serum adipokines and development of MM in $174 \mathrm{MM}$ patients and 348 controls within the Prostate, Lung, Colorectal, and Ovarian Cancer Screening Trial noted a significant inverse association between both total and high molecular weight adiponectin and subsequent risk of MM development, even in patients who were diagnosed with MM 8 or more years following blood collection. Fowler et al. [81] found direct in vivo evidence of an association between reduced adiponectin levels and progression of MM with the development of an increased tumour burden and osteolytic bone disease in myeloma-bearing adiponectin-deficient mice.

Moreover, an increased adiponectin level was observed to be protective, inducing myeloma cell apoptosis through activation of AMP-activated protein kinase (AMPK) in concordance with the tumour-suppressive effect of AMPK illustrated in other studies and suggesting that adiponectin may be a novel therapeutic target for MM and the related bone disease [81-84]. This data was supported by clinical evidence of decreased serum adiponectin in MGUS patients that later progressed to MM, and analysis of serum monoclonal protein concentration in this cohort demonstrated a significant inverse correlation between adiponectin and paraprotein concentration [81].
Another possible mechanism for these findings is that adiponectin suppresses nuclear factor $(\mathrm{KF})-\mathrm{\kappa B}$ activation and production of IL- 6 and TNF- $\alpha$ [85]; therefore its reduction may contribute to bone marrow overproduction of these cytokines [86]. Interestingly male gender, an established RF for MM, is associated with lower adiponectin levels [87]. Weight loss interventions may thus reduce the likelihood of developing MM and merit further research.

\section{The Impact of Lipid-Lowering and Antidiabetic Medication on MM Cell Lines}

Statins, competitive inhibitors of 3-hydroxy-3-methylglutaryl-coenzyme (HMG-CoA) reductase, are widely recognized to exert pleotropic effects in addition to their lipid-lowering properties [21]. There is accumulating evidence to suggest that statin use may reduce both the risk of development of MM and its mortality [88-91]. In vitro studies have shown that statins exert apoptosis-induced effects on myeloma cell lines $[88,89]$. Furthermore, a retrospective study of 4,957 patients reported a $21 \%$ decrease in all-cause mortality, a $24 \%$ reduction in MMassociated mortality, and a $31 \%$ reduction in myelomarelated skeletal events in patients with MM who received statin therapy [90].

Epstein et al. [91] assessed the relationship between model statin use ( $\geq 6$ cumulative months) and the risk of $\mathrm{MM}$, with examination of multiple latency periods in a case-control study of 2,532 cases and 9,805 controls. They reported a protective effect of statin therapy on risk of MM after adjusting for serum cholesterol level, with the greatest effect seen in patients who had a period of 48 months or more between the commencement of statin use and the diagnosis of MM, in addition to patients aged $\geq 70$ years regardless of the latency period. A period of 48-72 months between initiation of the statin and diagnosis was associated with a $20-28 \%$ reduction in MM development as compared to nonusers. Recent commencement of statins ( $<36$ months) was not associated with a reduced MM risk, suggesting that the beneficial effect of statins in protection against MM occurs early on in the carcinogenic process before the disease is biologically established [91].

Both natural and synthetic statins exert a cytotoxic effect on human myeloma tumour cells through activation of the mitochondrial pathway of apoptosis [92]. It has been suggested that mitochondrial disruption by statins leads to the release of cytochrome $\mathrm{c}$ from the intermem-
28

Acta Haematol 2021;144:24-32 DOI: $10.1159 / 000505992$
Ragbourne/Maghsoodi/Streetly/Crook 
Table 2. Summary of lipid-lowering drugs including metformin in MM and MGUS

\begin{tabular}{ll}
\hline Study & Type of study \\
\hline Becker et al. [18] & $\begin{array}{l}\text { Metformin had antitumour activity in } \\
\text { myeloma cell lines (review article) }\end{array}$ \\
\hline Otsuki et al. [88] & $\begin{array}{l}\text { Simvastatin killed myeloma cell lines } \\
\text { (experimental cell study) }\end{array}$ \\
\hline $\begin{array}{l}\text { Dirks and Jones } \\
\text { [89] }\end{array}$ & Statins killed myeloma cell lines (review) \\
\hline Sanfilippo et al. & $\begin{array}{l}\text { In 2,294 users, statins were associated with } \\
\text { reduced mortality (21\% decrease in MM) }\end{array}$ \\
\hline E0] & $\begin{array}{l}\text { 2,532 individuals on statins for 48-72 } \\
\text { months showed a 20-28\% reduced risk of } \\
\text { developing MM }\end{array}$ \\
\hline Cafforio et al. [92] & $\begin{array}{l}\text { Statins activate apoptosis in myeloma cell } \\
\text { lines }\end{array}$ \\
\hline Rizos and Elisaf & $\begin{array}{l}\text { Metformin decreased mortality in MM } \\
\text { (review) }\end{array}$ \\
\hline 99] & $\begin{array}{l}\text { In MGUS 3\% of metformin users progressed } \\
\text { to MM compared with 5\% non-users }\end{array}$ \\
\hline Chang et al. [98] & $\begin{array}{l}\text { Metformin killed myeloma cell line } \\
\text { (experimental cell studies) }\end{array}$ \\
\hline Zi et al. [101] & \\
\hline
\end{tabular}

brane space and formation of cytoplasmic apoptosome with activation of caspase 9. This subsequently activates effector caspases and triggers a cascade of events with resultant apoptosis [93-95]. They also impair the production of prenylated proteins leading to impaired cellular signalling and the induction of apoptosis with a potential therapeutic use in $\mathrm{MM}[96,97]$.

Anti-diabetic medications may also have an impact on MM risk and progression [30, 94, 98]. A retrospective study evaluated the effect of metformin use on progression of MGUS to MM in 2,003 patients, 23 and $77 \%$ of whom were users and nonusers of metformin, respectively. They found that metformin use for 4 or more years was associated with a reduced risk of transformation to $\mathrm{MM}$ $(\mathrm{HR}=0.47 ; 95 \% \mathrm{CI} 0.25-0.87)$, with a reported $3 \%$ of metformin users and $5 \%$ of nonusers progressing to $\mathrm{MM}$ [99]. Metformin may exert anti-carcinogenic activity through its effect on glycaemic control as well as a direct effect on myeloma cells [30].

Metformin is an AMPK activator, an enzyme that is involved in cellular energy homeostasis and cancer metabolism $[98,100]$. Furthermore, a recent study by $\mathrm{Zi}$ et al. [101] found that metformin inhibits the proliferation of myeloma cells by stimulating apoptosis and cell cycle arrest in the G0/G1 phase. Western blot analysis demonstrated that this occurred via a mitochondrial pathway with the activation of caspase 3 and other proapoptotic proteins and the significant inactivation of Mcl-1, a survival protein overexpressed in MM cells and associated with a poor prognosis [101]. The authors also reported that metformin inhibits the expression of insulin growth factor-1 receptor (IGF-1R), phosphatidylinositol 3-kinase (PI3K), protein kinase $\mathrm{B}(\mathrm{PKB} / \mathrm{AKT})$, and the downstream mammalian target of rapamycin (mTOR) and thereby inhibits the proliferation of myeloma cells via this signalling pathway [101]. There was also a synergistic anti-myeloma effect when metformin was combined with dexamethasone but not bortezomib [101]. It would be interesting to evaluate whether metformin use is additionally protective in the non-diabetic population. Metformin also specifically decreased IL-6R expression in myeloma cell lines [102]. See Table 2 for a summary of lipid-lowering drugs including metformin in MM and MGUS.

\section{Conclusion}

Substantial improvement has been made in the treatment of MM, with a current median OS about 7-10 years. The literature indicates an association between features of the MS and MM. The exact reason for this is not clear but may involve adipose derived cytokines and proinflammatory mediators that stimulate plasma cell activity and mitogenesis. In particular, adipocyte secretion of the stimulatory and oncogenic IL-6 appears pivotal in the pathogenesis of MM, which in turn may further elevate lipids. IGF-1 also appears significant in the development of MM, whilst metformin, an AMPK activator, appears to inhibit the proliferation of MM cell lines through the IGF-1R/PI3K/AKT/mTOR signalling pathway and acts synergistically with dexamethasone in the treatment of MM. Thus, addressing obesity may be important in MM. Long-term use of the lipid-lowering drugs the statins use may additionally play a protective role in MM development by impacting on early subclinical disease and sensitizing resistant MM cells to apoptosis.

These observations expose potentially exciting therapeutic interventions in the treatment of MGUS and MM. We would also suggest that the lipid profile, blood pressure, BMI, and glycaemic status be monitored in patients with MGUS and MM and an increased awareness of MS in these patients should be had. However, whilst there is evidence for a relationship between MS and MM, apart 
from the importance of controlling MS, there are no clinical trials to date that prospectively address the addition of cholesterol-lowering therapy or metformin usage in the treatment of MM. There are some currently ongoing trials; see clinicaltrials.gov [103], including: metformin and nelfinavir in treating patients with relapsed and/or refractory MM and looking at the clinical activity of metformin with high-dose of dexamethasone in relapse MM (METDEXA-MM). Hopefully such studies will prove fruitful and offer better outcomes for MM patients.

\section{Disclosure Statement}

The authors have no conflict of interests to declare.

\section{Funding Sources}

There are no funding sources to declare.

\section{Author Contributions}

M.A.C.: guarantor.

\section{References}

1 WHO: 10 facts on obesity; World Health Organization [updated October 2017], Retrieved 29th December 2017.

2 Berrington de Gonzalez A, Hartge P, Cerhan JR, Flint AJ, Hannan L, MacInnis RJ, et al. Body-mass index and mortality among 1.46 million white adults. N Engl J Med. 2010 Dec; 363(23):2211-9.

3 Arnold M, Pandeya N, Byrnes G, Renehan PA, Stevens GA, Ezzati PM, et al. Global burden of cancer attributable to high body-mass index in 2012: a population-based study. Lancet Oncol. 2015 Jan;16(1):36-46.

4 Arnold M, Leitzmann M, Freisling H, Bray F, Romieu I, Renehan A, et al. Obesity and cancer: an update of the global impact. Cancer Epidemiol. 2016 Apr;41:8-15.

5 Calle EE, Rodriguez C, Walker-Thurmond K, Thun MJ. Overweight, obesity, and mortality from cancer in a prospectively studied cohort of U.S. adults. N Engl J Med. 2003 Apr; 348(17): 1625-38.

6 Larsson SC, Wolk A. Body mass index and risk of multiple myeloma: a meta-analysis. Int J Cancer. 2007 Dec;121(11):2512-6.

7 Wallin A, Larsson SC. Body mass index and risk of multiple myeloma: a meta-analysis of prospective studies. Eur J Cancer. 2011 Jul; 47(11):1606-15.

8 De Pergola G, Silvestris F. Obesity as a major risk factor for cancer. J Obes. 2013;2013: 291546.

9 Renehan AG, Tyson M, Egger M, Heller RF, Zwahlen M. Body-mass index and incidence of cancer: a systematic review and meta-analysis of prospective observational studies. Lancet. 2008 Feb;371(9612):569-78.

10 Morgan GJ, Davies FE, Linet M. Myeloma aetiology and epidemiology. Biomed Pharmacother. 2002 Jul;56(5):223-34.

11 Alexander DD, Mink PJ, Adami HO, Cole P, Mandel JS, Oken MM, et al. Multiple myeloma: a review of the epidemiologic literature. Int J Cancer. 2007;120(Suppl 12):40-61.

12 Nagel G, Stocks T, Späth D, Hjartåker A, Lindkvist B, Hallmans G, et al. Metabolic factors and blood cancers among 578,000 adults in the metabolic syndrome and cancer project (Me-Can). Ann Hematol. 2012 Oct;91(10):1519-31.
13 Hofmann JN, Moore SC, Lim U, Park Y, Baris $\mathrm{D}$, Hollenbeck AR, et al. Body mass index and physical activity at different ages and risk of multiple myeloma in the NIH-AARP diet and health study. Am J Epidemiol. 2013 Apr; 177(8):776-86.

14 Lauby-Secretan B, Scoccianti C, Loomis D, Grosse Y, Bianchini F, Straif K; International Agency for Research on Cancer Handbook Working Group. Body Fatness and CancerViewpoint of the IARC Working Group. N Engl J Med. 2016 Aug;375(8):794-8.

15 Lichtman MA. Obesity and the risk for a hematological malignancy: leukemia, lymphoma, or myeloma. Oncologist. 2010;15(10): 1083-101.

16 Murphy F, Kroll ME, Pirie K, Reeves G, Green $\mathrm{J}$, Beral V. Body size in relation to incidence of subtypes of haematological malignancy in the prospective Million Women Study. Br J Cancer. 2013 Jun;108(11):2390-8.

17 Teras LR, Kitahara CM, Birmann BM, Hartge PA, Wang SS, Robien K, et al. Body size and multiple myeloma mortality: a pooled analysis of 20 prospective studies. Br J Haematol. 2014 Sep;166(5):667-76.

18 Becker S, Dossus L, Kaaks R. Obesity related hyperinsulinaemia and hyperglycaemia and cancer development. Arch Physiol Biochem. 2009 May;115(2):86-96.

19 Carson KR, Bates ML, Tomasson MH. The skinny on obesity and plasma cell myeloma: a review of the literature. Bone Marrow Transplant. 2014 Aug;49(8):1009-15.

20 Thompson MA, Kyle RA, Melton LJ 3rd, Plevak MF, Rajkumar SV. Effect of statins, smoking and obesity on progression of monoclonal gammopathy of undetermined significance: a case-control study. Haematologica. 2004 May;89(5):626-8.

21 Beason TS, Chang SH, Sanfilippo KM, Luo S, Colditz GA, Vij R, et al. Influence of body mass index on survival in veterans with multiple myeloma. Oncologist. 2013;18(10): 1074-9.

22 Ragbourne SC, Crook MA. Metabolic Syndrome in Long-Term Survivors of Hematopoietic Stem-Cell Transplantation. Clin Lymphoma Myeloma Leuk. 2017 Jun;17(6):340-6.
23 Braun S, Bitton-Worms K, LeRoith D. The link between the metabolic syndrome and cancer. Int J Biol Sci. 2011;7(7):1003-15.

24 Esposito K, Chiodini P, Colao A, Lenzi A, Giugliano D. Metabolic syndrome and risk of cancer: a systematic review and meta-analysis. Diabetes Care. 2012 Nov;35(11):2402-11.

25 Streetly M, Milner G, Kazmi M, El-Najjar I, Schey S, Crook MA. Myeloma is associated with features of metabolic syndrome. Clin Lymphoma Myeloma Leuk. 2015;15:e253-4.

26 Richardson LC, Pollack LA. Therapy insight: influence of type 2 diabetes on the development, treatment and outcomes of cancer. Nat Clin Pract Oncol. 2005 Jan;2(1):48-53.

27 Khan AE, Gallo V, Linseisen J, Kaaks R, Rohrmann S, Raaschou-Nielsen $\mathrm{O}$, et al.; EPIC Group. Diabetes and the risk of nonHodgkin's lymphoma and multiple myeloma in the European Prospective Investigation into Cancer and Nutrition. Haematologica. 2008 Jun;93(6):842-50.

28 Chiu BC, Gapstur SM, Greenland P, Wang R, Dyer A. Body mass index, abnormal glucose metabolism, and mortality from hematopoietic cancer. Cancer Epidemiol Biomarkers Prev. 2006 Dec;15(12):2348-54.

29 Castillo JJ, Mull N, Reagan JL, Nemr S, Mitri $\mathrm{J}$. Increased incidence of non-Hodgkin lymphoma, leukemia, and myeloma in patients with diabetes mellitus type 2 : a meta-analysis of observational studies. Blood. 2012 May; 119(21):4845-50.

30 Chou YS, Yang CF, Chen HS, Yang SH, Yu $\mathrm{YB}$, Hong YC, et al. Pre-existing diabetes mellitus in patients with multiple myeloma. Eur J Haematol. 2012 Oct;89(4):320-7.

31 Wu W, Merriman K, Nabaah A, Seval N, Seval $\mathrm{D}$, Lin $\mathrm{H}$, et al. The association of diabetes and anti-diabetic medications with clinical outcomes in multiple myeloma. Br J Cancer. 2014 Jul;111(3):628-36

32 Roberts-Thomson PJ, Venables GS, Onitiri AC, Lewis B. Polymeric IgA myeloma, hyperlipidaemia and xanthomatosis: a further case and review. Postgrad Med J. 1975 Jan;51(591):44-51.

33 Beaumont JL, Beaumont V. Autoimmune hyperlipidemia. Atherosclerosis. 1977 Apr; 26(4):405-18. 
34 Misselwitz B, Goede JS, Pestalozzi BC, Schanz U, Seebach JD. Hyperlipidemic myeloma: review of 53 cases. Ann Hematol. 2010 Jun; 89(6):569-77.

35 Fukudome K, Kato J, Ohashi T, Yamamoto Y, Eto T. Hyperlipidemia associated with multiple myeloma. Intern Med. 1996 Apr;35(4): 337-40.

36 van de Donk NW, Palumbo A, Johnsen HE, Engelhardt M, Gay F, Gregersen H, et al.; European Myeloma Network. The clinical relevance and management of monoclonal gammopathy of undetermined significance and related disorders: recommendations from the European Myeloma Network. Haematologica. 2014 Jun;99(6):984-96.

37 Kihara S, Matsuzawa Y, Kubo M, Nozaki S, Funahashi T, Yamashita S, et al. Autoimmune hyperchylomicronemia. N Engl J Med. 1989 May;320(19):1255-9.

38 Chee L, Spearing RL, Morris CM, McDonald M, Hanrahan V, Ebbett A, et al. Acquired myeloma-associated Type III hyperlipidaemia treated by nonmyeloablative HLAidentical sibling allogeneic stem cell transplant using a donor with essential thrombocythaemia (ET): evidence of engraftment without manifestation of ET in recipient. Bone Marrow Transplant. 2005 Jun;35(12): 1213-4.

39 Aviram M, Carter A, Brook JG, Tatarsky I. Chylomicronaemia in multiple myeloma. Scand J Haematol. 1985 May;34(5):436-41.

40 Burnside NJ, Alberta L, Robinson-Bostom L, Bostom A. Type III hyperlipoproteinemia with xanthomas and multiple myeloma. J Am Acad Dermatol. 2005 Nov;53(5 Suppl 1):S281-4.

41 Nozaki S, Ito Y, Nakagawa T, Yamashita S, Sasaki J, Matsuzawa Y. Autoimmune hyperlipidemia with inhibitory monoclonal antibodies against low density lipoprotein binding to fibroblasts in a case with multiple myeloma. Intern Med. 1997 Dec;36(12): 920-5.

42 Kilgore LL, Patterson BW, Parenti DM, Fisher WR. Immune complex hyperlipidemia induced by an apolipoprotein-reactive immunoglobulin A paraprotein from a patient with multiple myeloma. Characterization of this immunoglobulin. J Clin Invest. 1985 Jul; 76(1):225-32.

43 Corsini A, Roma P, Sommariva D, Fumagalli R, Catapano AL. Autoantibodies to the low density lipoprotein receptor in a subject affected by severe hypercholesterolemia. J Clin Invest. 1986 Oct;78(4):940-6.

44 Taylor JS, Lewis LA, Battle JD Jr, Butkus A, Robertson AL, Deodhar S, et al. Plane xanthoma and multiple myeloma with lipoprotein-paraprotein complexing. Arch Dermatol. 1978 Mar;114(3):425-31

45 Cortese C, Lewis B, Miller NE, Peyman MA, Rao SN, Slavin B, et al. Myelomatosis with type III hyperlipoproteinemia: clinical and metabolic studies. N Engl J Med. 1982 Jul; 307(2):79-83.
46 Baudet MF, Dachet C, Beaumont JL. In vitro interaction of LDL, anti-lipoprotein IgA and human fibroblasts. Biomedicine. 1978 Oct; 29(6):217-20

47 Beaumont JL, Berard M, Antonucci M, Delplanque B, Vranckx R. Inhibition of lipoprotein lipase activity by a monoclonal immunoglobulin in autoimmune hyperlipidemia. Atherosclerosis. 1977 Jan;26(1):67-77.

48 Glueck HI, MacKenzie MR, Glueck CJ. Crystalline IgG protein in multiple myeloma: identification effects on coagulation and on lipoprotein metabolism. J Lab Clin Med. 1972 May;79(5):731-44.

49 Beaumont JL, Antonucci M, Lagrue G, Guedon J, Perol R. Nephrotic syndrome, monoclonal gammopathy and auto-immune hyperlipidaemia. Clin Exp Immunol. 1974 Oct; 18(2):225-36

50 Tirado-Vélez JM, Benítez-Rondán A, CózarCastellano I, Medina F, Perdomo G. Lowdensity lipoprotein cholesterol suppresses apoptosis in human multiple myeloma cells. Ann Hematol. 2012 Jan;91(1):83-8.

51 Chen JK, Okamoto T, Sato JD, Sato GH, McClure DB. Biochemical characterization of the cholesterol-dependent growth of the NS-1 mouse myeloma cell line. Exp Cell Res. 1986 Mar;163(1):117-26.

52 Shahbaz A, Aziz K, Umair M, Zarghamravanbakhsh M, Sachmechi I. A Patient with Artifactually Low Serum High Density Lipoprotein Cholesterol Due to Waldenstrom Macroglobulinemia. Cureus. 2018 Jun;10(6):e2900.

53 Chari A, Mezzi K, Zhu S, Werther W, Felici D, Lyon AR. Incidence and risk of hypertension in patients newly treated for multiple myeloma: a retrospective cohort study. BMC Cancer. 2016 Nov;16(1):912.

54 Patel VG, Cornell RF. Cardiovascular Complications Associated with Multiple Myeloma Therapies: Incidence, Pathophysiology, and Management. Curr Oncol Rep. 2019 Mar; 21(4):29.

55 Bruno G, Bringhen S, Maffei I, Iannaccone A, Crea T, Ravera A, et al. Cardiovascular Organ Damage and Blood Pressure Levels Predict Adverse Events in Multiple Myeloma Patients Undergoing Carfilzomib Therapy. Cancers (Basel). 2019 May;11(5):E622.

56 Bringhen S, Milan A, D’Agostino M, Ferri C, Wäsch R, Gay F, et al. Prevention, monitoring and treatment of cardiovascular adverse events in myeloma patients receiving carfilzomib A consensus paper by the European Myeloma Network and the Italian Society of Arterial Hypertension. J Intern Med. 2019 Jul; 286(1):63-74.

57 Pickup JC, Crook MA. Is type II diabetes mellitus a disease of the innate immune system? Diabetologia. 1998 Oct;41(10):1241-8.

58 Pickup JC. Inflammation and activated innate immunity in the pathogenesis of type 2 diabetes. Diabetes Care. 2004 Mar;27(3):813-23.

59 Crook M. Type 2 diabetes mellitus: a disease of the innate immune system? An update. Diabet Med. 2004 Mar;21(3):203-7.
60 Chandran M, Phillips SA, Ciaraldi T, Henry RR. Adiponectin: more than just another fat cell hormone? Diabetes Care. 2003 Aug;26(8): 2442-50.

61 Kershaw EE, Flier JS. Adipose tissue as an endocrine organ. J Clin Endocrinol Metab. 2004 Jun;89(6):2548-56.

62 Dalamaga M, Karmaniolas K, Panagiotou A, Hsi A, Chamberland J, Dimas C, et al. Low circulating adiponectin and resistin, but not leptin, levels are associated with multiple myeloma risk: a case-control study. Cancer Causes Control. 2009 Mar;20(2):193-9.

63 Murray PJ. The JAK-STAT signaling pathway: input and output integration. J Immunol. 2007 Mar; 178(5):2623-9.

64 Liu Y, Li PK, Li C, Lin J. Inhibition of STAT3 signaling blocks the anti-apoptotic activity of IL-6 in human liver cancer cells. J Biol Chem. 2010 Aug;285(35):27429-39.

65 Hitzler JK, Martinez-Valdez H, Bergsagel DB, Minden MD, Messner HA. Role of interleukin-6 in the proliferation of human multiple myeloma cell lines OCI-My 1 to 7 established from patients with advanced stage of the disease. Blood. 1991 Oct;78(8):1996-2004.

66 Collette M, Descamps G, Pellat-Deceunynck C, Bataille R, Amiot M. Crucial role of phosphatase CD45 in determining signaling and proliferation of human myeloma cells. Eur Cytokine Netw. 2007 Sep;18(3):120-6.

67 Naka T, Nishimoto N, Kishimoto T. The paradigm of IL-6: from basic science to medicine. Arthritis Res. 2002;4 Suppl 3:S233-42.

68 Sprynski AC, Hose D, Caillot L, Réme T, Shaughnessy JD Jr, Barlogie B, et al. The role of IGF-1 as a major growth factor for myeloma cell lines and the prognostic relevance of the expression of its receptor. Blood. 2009 May;113(19):4614-26.

69 Lauta VM. A review of the cytokine network in multiple myeloma: diagnostic, prognostic, and therapeutic implications. Cancer. 2003 May;97(10):2440-52.

70 Pelliniemi TT, Irjala K, Mattila K, Pulkki K, Rajamäki A, Tienhaara A, et al.; Finnish Leukemia Group. Immunoreactive interleukin- 6 and acute phase proteins as prognostic factors in multiple myeloma. Blood. 1995 Feb;85(3): 765-71.

71 Kahn BB, Flier JS. Obesity and insulin resistance. J Clin Invest. 2000 Aug;106(4):473-81.

72 Conover CA, Lee PD, Kanaley JA, Clarkson $\mathrm{JT}$, Jensen MD. Insulin regulation of insulinlike growth factor binding protein-1 in obese and nonobese humans. J Clin Endocrinol Metab. 1992 Jun;74(6):1355-60.

73 Freund GG, Kulas DT, Mooney RA. Insulin and IGF-1 increase mitogenesis and glucose metabolism in the multiple myeloma cell line, RPMI 8226. J Immunol. 1993 Aug;151(4): 1811-20.

74 Georgii-Hemming P, Wiklund HJ, Ljunggren $\mathrm{O}$, Nilsson K. Insulin-like growth factor I is a growth and survival factor in human multiple myeloma cell lines. Blood. 1996 Sep;88(6): 2250-8. 
75 Ferlin M, Noraz N, Hertogh C, Brochier J, Taylor N, Klein B. Insulin-like growth factor induces the survival and proliferation of myeloma cells through an interleukin-6-independent transduction pathway. Br J Haematol. 2000 Nov;111(2):626-34.

76 Menu E, van Valckenborgh E, van Camp B, Vanderkerken $\mathrm{K}$. The role of the insulin-like growth factor 1 receptor axis in multiple myeloma. Arch Physiol Biochem. 2009 May; 115(2):49-57.

77 Menu E, Asosingh K, Van Riet I, Croucher P, Van Camp B, Vanderkerken K. Myeloma cells (5TMM) and their interactions with the marrow microenvironment. Blood Cells Mol Dis. 2004 Sep-Oct;33(2):111-9.

78 Gavrila A, Chan JL, Yiannakouris N, Kontogianni M, Miller LC, Orlova C, et al. Serum adiponectin levels are inversely associated with overall and central fat distribution but are not directly regulated by acute fasting or leptin administration in humans: cross-sectional and interventional studies. J Clin Endocrinol Metab. 2003 Oct;88(10):4823-31.

79 Hug C, Lodish HF. The role of the adipocyte hormone adiponectin in cardiovascular disease. Curr Opin Pharmacol. 2005 Apr;5(2): $129-34$.

80 Hofmann JN, Liao LM, Pollak MN, Wang Y, Pfeiffer RM, Baris D, et al. A prospective study of circulating adipokine levels and risk of multiple myeloma. Blood. 2012 Nov;120(22): 4418-20.

81 Fowler JA, Lwin ST, Drake MT, Edwards JR, Kyle RA, Mundy GR, et al. Host-derived adiponectin is tumor-suppressive and a novel therapeutic target for multiple myeloma and the associated bone disease. Blood. 2011 Nov; 118(22):5872-82.

82 Alexandrakis MG, Passam FH, Sfiridaki A, Pappa CA, Moschandrea JA, Kandidakis E, et al. Serum levels of leptin in multiple myeloma patients and its relation to angiogenic and inflammatory cytokines. Int J Biol Markers. 2004 Jan-Mar;19(1):52-7.
83 Pamuk GE, Demir M, Harmandar F, Yesil Y, Turgut B, Vural O. Leptin and resistin levels in serum of patients with hematologic malignancies: correlation with clinical characteristics. Exp Oncol. 2006 Sep;28(3):241-4.

84 Baumann P, Mandl-Weber S, Emmerich B, Straka C, Schmidmaier R. Activation of adenosine monophosphate activated protein kinase inhibits growth of multiple myeloma cells. Exp Cell Res. 2007 Oct;313(16):3592603.

85 Ajuwon KM, Spurlock ME. Adiponectin inhibits LPS-induced NF-kappaB activation and IL-6 production and increases PPARgamma2 expression in adipocytes. Am J Physiol Regul Integr Comp Physiol. 2005 May;288(5):R1220-5.

86 Dalamaga M, Diakopoulos KN, Mantzoros CS. The role of adiponectin in cancer: a review of current evidence. Endocr Rev. 2012 Aug; 33(4):547-94.

87 Oh DK, Ciaraldi T, Henry RR. Adiponectin in health and disease. Diabetes Obes Metab. 2007 May; 9(3):282-9.

88 Otsuki T, Sakaguchi H, Eto M, Fujii T, Hatayama T, Takata A, et al. IL-6 is a key factor in growth inhibition of human myeloma cells induced by pravastatin, an HMG-CoA reductase inhibitor. Int J Oncol. 2003 Sep;23(3): 763-8.

89 Dirks AJ, Jones KM. Statin-induced apoptosis and skeletal myopathy. Am J Physiol Cell Physiol. 2006 Dec;291(6):C1208-12.

90 Sanfilippo KM, Keller J, Gage BF, Luo S, Wang TF, Moskowitz G, et al. Statins Are Associated With Reduced Mortality in Multiple Myeloma. J Clin Oncol. 2016 Nov;34(33): 4008-14.

91 Epstein MM, Divine G, Chao CR, Wells KE, Feigelson HS, Scholes D, et al. Statin use and risk of multiple myeloma: an analysis from the cancer research network. Int J Cancer. 2017 Aug;141(3):480-7.

92 Cafforio P, Dammacco F, Gernone A, Silvestris F. Statins activate the mitochondrial pathway of apoptosis in human lymphoblasts and myeloma cells. Carcinogenesis. 2005 May; 26(5):883-91.
93 Matsuura K, Canfield K, Feng W, Kurokawa M. Metabolic Regulation of Apoptosis in Cancer. Int Rev Cell Mol Biol. 2016;327:4387.

94 Suzuki Y, Imai Y, Nakayama H, Takahashi $\mathrm{K}$, Takio K, Takahashi R. A serine protease, HtrA2, is released from the mitochondria and interacts with XIAP, inducing cell death. Mol Cell. 2001 Sep;8(3):613-21.

95 Bénit P, Lebon S, Rustin P. Respiratorychain diseases related to complex III deficiency. Biochim Biophys Acta. 2009 Jan; 1793(1):181-5.

96 Stock J. Statin-associated muscle symptoms EAS Consensus Panel paper focuses on this neglected patient group. Atherosclerosis. 2015 Sep;242(1):346-50.

97 Kumar SK, Rajkumar SV, Dispenzieri A, Lacy MQ, Hayman SR, Buadi FK, et al. Improved survival in multiple myeloma and the impact of novel therapies. Blood. 2008 Mar;111(5):2516-20.

98 Chang SH, Luo S, O’Brian KK, Thomas TS, Colditz GA, Carlsson NP, et al. Association between metformin use and progression of monoclonal gammopathy of undetermined significance to multiple myeloma in US veterans with diabetes mellitus: a populationbased retrospective cohort study. Lancet Haematol. 2015 Jan;2(1):e30-6.

99 Rizos CV, Elisaf MS. Metformin and cancer Eur J Pharmacol. 2013 Apr;705(1-3):96108.

100 Wang W, Guan KL. AMP-activated protein kinase and cancer. Acta Physiol (Oxf). 2009 May;196(1):55-63.

101 Zi FM, He JS, Li Y, Wu C, Yang L, Yang Y, et al. Metformin displays anti-myeloma activity and synergistic effect with dexamethasone in in vitro and in vivo xenograft models. Cancer Lett. 2015 Jan;356(2 Pt B):44353.

102 Mishra AK, Dingli D. Metformin inhibits IL-6 signaling by decreasing IL-6R expression on multiple myeloma cells. Leukemia. 2019 Nov;33(11):2695-709.

103 Clinical trial.gov. website https://clinicaltrials.gov/ct2/search. 